\title{
ENDOPARASITES IN BIRDS OF GUARIBAS BIOLOGICAL RESERVE, ATLANTIC FOREST, PARAÍBA STATE, BRAZIL
}

\section{ENDOPARASITOS NAS AVES DA RESERVA BIOLÓGICA GUARIBAS, PARAÍBA, BRASIL}

\author{
Camile Lugarini ${ }^{1,2^{*}}$ \\ Maria Clara Feitosa de Albuquerque ${ }^{2}$ \\ Ralph Eric Thijl Vanstreels ${ }^{3}$ \\ Andrei Langeloh Roos ${ }^{1}$ \\ Jean Carlos Ramos Silva ${ }^{2}$ \\ Jaqueline Bianque de Oliveira ${ }^{2}$ \\ 1 Instituto Chico Mendes de Conservação da Biodiversidade, Brasília, DF, Brazil. \\ 2 Universidade Federal Rural de Pernambuco, Recife, PE, Brazil. \\ ${ }^{3}$ Faculdade de Medicina Veterinária e Zootecnia da Universidade de São Paulo, São Paulo, SP, Brazil. \\ *Corresponding author - camile.lugarini@icmbio.gov.br
}

\begin{abstract}
This paper describes the findings on endoparasites in Atlantic forest birds at Guaribas Biological Reserve, Paraíba State, Northeast of Brazil. We captured 151 birds with mist nets in ten field expeditions between July 2010 and June 2011 and studied bird endoparasites through blood and excreta samples. Blood samples were collected from 131 birds and excreta were collected from 48 birds. In blood smears, only Haemoproteus columbae was detected in three Columbiformes (2.29\%) of the species Columbina talpacoti. Fecal samples were collected from 48 birds, and eggs of nematodes and oocysts of coccidian were detected in $6.25 \%$ of the samples: Spirurida (Nematoda) in Lanio cristatus (Thraupidae); Strongyloides sp. (Nematoda) in Momotus momota (Momotidae) and Isospora sp. (Protozoa, Eimeriidae) in Neopelma pallescens (Pipridae). There is limited information about the parasites of wild birds in the remaining fragments of Atlantic forest in Northeast of Brazil; however, such knowledge can help understanding these host-parasite interactions.
\end{abstract}

Keywords: gastrointestinal parasites; Haemosporidia; protected area

\section{Resumo}

Este artigo descreve os achados de endoparasitos em aves da Reserva Biológica Guaribas, no estado da Paraíba, Nordeste do Brasil. Foram capturadas 151 aves por meio de rede de neblina em dez expedições de campo entre julho de 2010 a junho de 2011, efetuando-se a colheita de sangue e excreta para a realização do estudo de endoparasitos. Foram analisadas 131 amostras de sangue e 48 amostras de fezes. Nas amostras de sangue foi detectado apenas Haemoproteus columbae em três Columbiformes (2.29\%) da espécie Columbina talpacoti. Ovos de nematódeos e oocistos de protozoários foram detectados em 6,25\% das amostras de fezes: Spirurida (Nematoda) em Lanio cristatus (Thraupidae); Strongyloides sp. (Nematoda) em Momotus momota (Momotidae) e Isospora sp. (Protozoa, Eimeriidae) em Neopelma pallescens (Pipridae). Poucas informações sobre o parasitismo nos fragmentos da Mata Atlântica do Nordeste estão disponíveis e o seu conhecimento pode auxiliar a compreensão da interação parasite-hospedeiro.

Palavras-chave: hemoparasitos; parasitos gastrintestinais; unidade de conservação

Received on: June $16^{\text {th }}, 2014$

Accepted on: January $29^{\text {th }}, 2018$

Cienc. anim. bras., Goiânia, v.19, 1-8, e-30480, 2018 


\section{Introduction}

Brazil stands out for its high biodiversity and species endemism, as well as for its unfortunately high rates of habitat degradation ${ }^{(1)}$. Anthropogenic pressure has constrained wildlife populations to small protected areas, increasing their densities and favoring pathogens transmission ${ }^{(2)}$.

Birds host a variety of parasites of diverse forms and life cycles. Understanding the behavior and environmental requirements of bird hosts and their parasites is important to evaluate the role played by the landscape in determining the parasite fauna of a species ${ }^{(3)}$. Parasitism may contribute to the structure, conservation, and function of biodiversity ${ }^{(4)}$ and sometimes parasites can also cause distress, decrease reproductive success and increase mortality ${ }^{(5,6)}$.

In this paper, we describe the findings on endoparasites in a bird population in one of the few remaining Atlantic forest fragments surrounded by sugar cane monoculture in Northeast Brazil, the Guaribas Biological Reserve, in the state of Paraiba.

\section{Material and Methods}

Guaribas Biological Reserve is considered an Important Bird Area (IBA) ${ }^{(7)}$ (Figure 1) and it is subdivided into three fragments. This study was carried out in fragment II, a $30 \mathrm{~km}^{2}$ area located in the municipality of Mamanguape (06 $40^{\circ} 40^{\prime \prime}-06^{\circ} 44^{\prime} 59^{\prime \prime} \mathrm{S}$ and $\left.41^{\circ} 12^{\prime} 47^{\prime \prime}-41^{\circ} 07^{\prime} 11^{\prime \prime} \mathrm{W}\right)$, state of Paraíba, Brazil. The landscape is composed of areas of cerrado vegetation, frequently called 'tabuleiro', where endemic and threatened bird taxa are known to occur ${ }^{(8)}$.
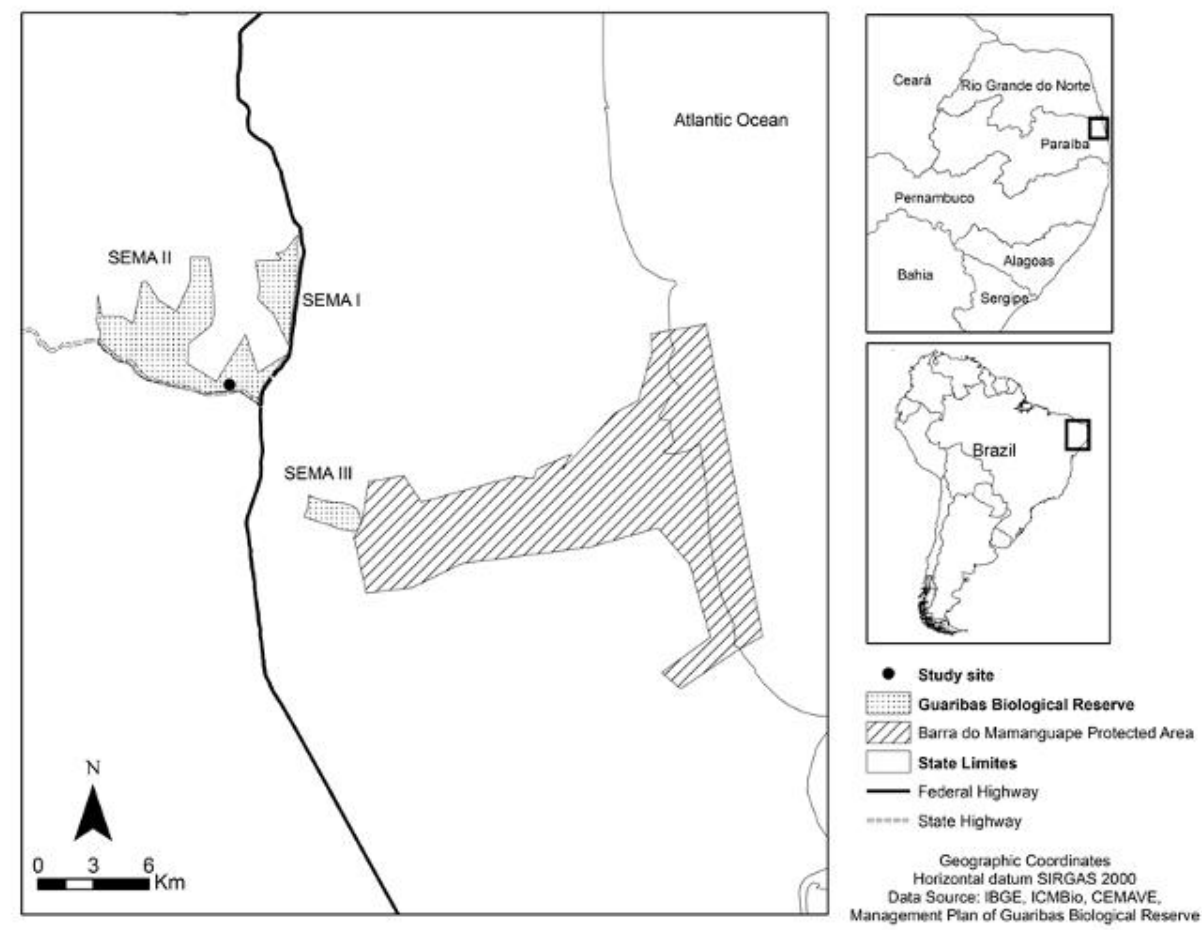

Figure 1. Guaribas Biological Reserve, state of Paraiba, Brazil, showing the three fragments of the protected area called SEMA I, II, and III. The fragment's names follow the formal designation as the protected area was previously managed by the Secretaria de Meio Ambiente da Paraíba (Environment Office of Paraiba state). 
Birds were captured during ten field expeditions between July 2010 and June 2011. For two days during each field expedition, we captured birds using fifteen mist nets $(2.5 \times 12$ meters, 36-mm mesh) set up in three parallel lines, 100 meters apart, and opened between 05:00 and 10:00 a.m. We carried out a clinical examination of the birds and visualized no clinical signs in all captured birds. Care was taken to minimize stress and mortality did not exceed 1\%. Individuals considered stressed or presenting lethargy, closed eyes, and/or labored breathing were immediately released at the location of processing. Sampled individuals were released immediately after the sampling procedures at the processing station. The project was approved by the Council of Ethics at Universidade Federal Rural de Pernambuco under number 040/2013 and SISBIO under number 23405.

Fecal samples were collected from the cloth bags in which the birds had been placed until processing or from spontaneous defecation during handling. Samples were placed into microtubes containing saline solution and maintained under refrigeration. Due to the small quantity of feces collected, we used a Sheather flotation technique, with fecal samples being placed in a saturated sucrose solution (density $1.3 \mathrm{~d}$ ) to examine samples for parasites according to Santos et al. ${ }^{(9)}$. The identification of eggs and oocysts was made according to Foreyt $^{(10)}$ and Zajac and Conboy ${ }^{(11)}$.

Blood samples were collected from the ulnar vein or toenails; the collected volume was lower than $1 \%$ of the body mass ${ }^{(12)}$. Blood smears were immediately prepared, air-dried, and stained with May-Grunwald-Giemsa solution modified by Rosenfeld ${ }^{(13)}$. Slides were examined with a light microscope during 25 to 30 minutes. Approximately 100 microscopic fields were examined on low magnification (400x) and 100 fields on high magnification $(1000 \mathrm{x})$ under oil-immersion ${ }^{(14)}$. Blood parasites were morphologically identified ${ }^{(15)}$, and parasitemia was estimated following the recommendations of Godfrey et al. ${ }^{(16)}$, using automated erythrocyte counts $^{(17)}$.

\section{Results and Discussion}

A total 152 individuals were sampled across seven orders and 19 families (Table 1). Blood smears were collected from 131 individuals, and blood parasites were detected in three individuals (2.19\%), all of them were adult Columbina talpacoti (Columbidae). Blood smears presented no erythrocytic meronts, a low frequency of trophozoites (0-14\%), and a large proportion of macro (60-71\%) and microgametocytes (14$40 \%$ ); only mature erythrocytes were parasitized. Gametocytes presented in the shape of an elongated ' $\mathrm{C}$ ', embracing the nuclei but not involving it completely, and occupied approximately $40-70 \%$ of the area of the cytoplasm. In most cases, the nucleus of parasitized erythrocyte was slightly to moderately displaced and the parasite marginally touched the nuclear membrane of the host cell, but contact was not complete and sometimes did not occur. The outer contour of erythrocytes was not significantly deformed. Parasite nuclei were median or submedian and intermediate in size. Few small white vacuoles (typically 1-3) could be observed in the cytoplasm of macrogametocytes. Macrogametocytes contained a large quantity of pigment granules (typically 15-30) irregularly distributed in the cytoplasm, sometimes found in groups of 2-5, in apparently irregular, large granules. The microgametocytes had fewer granules (typically 8-20), which were irregularly distributed and tended to accumulate in the parasitic poles, sometimes grouped into larger granules. In all cases, these morphological characteristics were considered compatible with Haemoproteus columbae (Kruse 1980) (Figure 2). Parasitemia was markedly low ( $<0.1 \%$ of erythrocytes in two cases, $0.15 \%$ in one case) and no significant indications of regenerative anemia were observed (in all cases, reticulocytes corresponded to $<10 \%$ of the erythrocytes). 
Table 1. Hosts sampled for parasites in the Guaribas Biological Reserve, Paraiba state, Brazil, from July 2010-June 2011. The taxonomy followed Piacentini et al.(18)

\begin{tabular}{lccc}
\hline Hosts & $\begin{array}{c}\text { Number of } \\
\text { captured hosts }\end{array}$ & $\begin{array}{c}\text { Blood } \\
\text { samples }\end{array}$ & $\begin{array}{c}\text { Fecal } \\
\text { samples }\end{array}$ \\
\hline Accipitridae Rupornis magnirostris (Gmelin, 1788) & 1 & 1 & 0 \\
Columbidae Columbina talpacoti (Temminck, 1811) & 5 & 4 & 2 \\
Cuculidae Piaya cayana (Linnaeus, 1766) & 1 & 1 & 0 \\
Trogonidae Trogon curucui Linnaeus, 1766 & 1 & 1 & 1 \\
Momotidae Momotus momota (Linnaeus, 1766) & 2 & 2 & 1 \\
Picidae Picumnus fulvescens Stager, 1961 & 1 & 0 & 1 \\
Thamnophilidae Formicivora grisea (Boddaert, 1783) & 5 & 4 & 1 \\
Thamnophilidae Thamnophilus pelzelni Hellmayr, 1924 & 5 & 5 & 2 \\
Conopophagidae Conopophaga lineata (Wied, 1831) & 1 & 1 & 0 \\
Furnariidae Xenops minutus (Sparrman, 1788) & 1 & 1 & 0 \\
Pipridae Neopelma pallescens (Lafresnaye, 1853) & 53 & 44 & 23 \\
Pipridae Chiroxiphia pareola (Linnaeus, 1766) & 2 & 0 & 2 \\
Tityridae Pachyramphus polychopterus (Vieillot, 1818) & 2 & 2 & 0 \\
Rhynchocyclidae Tolmomyias flaviventris (Wied, 1831) & 3 & 2 & 2 \\
Tyrannidae Elaenia cristata Pelzeln, 1868 & 7 & 6 & 1 \\
Tyrannidae Cnemotriccus fuscatus (Wied, 1831) & 1 & 1 & 1 \\
Vireonidae Cyclarhis gujanensis (Gmelin, 1789) & 1 & 1 & 0 \\
Vireonidae Vireo chivi (Vieillot, 1817) & 5 & 5 & 0 \\
Polioptilidae Polioptila plumbea (Gmelin, 1788) & 1 & 1 & 0 \\
Turdidae Turdus leucomelas Vieillot, 1818 & 9 & 8 & 2 \\
Passerellidae Arremon taciturnus (Hermann, 1783) & 3 & 3 & 1 \\
Parulidae Basileuterus culicivorus (Deppe, 1830) & 5 & 4 & 1 \\
Parulidae Myiothlypis flaveola Baird, 1865 & 3 & 3 & 0 \\
Thraupidae Tangara cayana (Linnaeus, 1766) & 9 & 8 & 3 \\
Thraupidae Lanio cristatus (Linnaeus, 1766) & 4 & 3 & 2 \\
Thraupidae Tachyphonus rufus (Boddaert, 1783) & 10 & 10 & 0 \\
Thraupidae Cyanerpes cyaneus (Linnaeus, 1766) & 3 & 3 & 1 \\
Thraupidae Dacnis cayana (Linnaeus, 1766) & 3 & 3 & 1 \\
Thraupidae Coereba flaveola (Linnaeus, 1758) & 4 & 4 & 0 \\
\hline
\end{tabular}

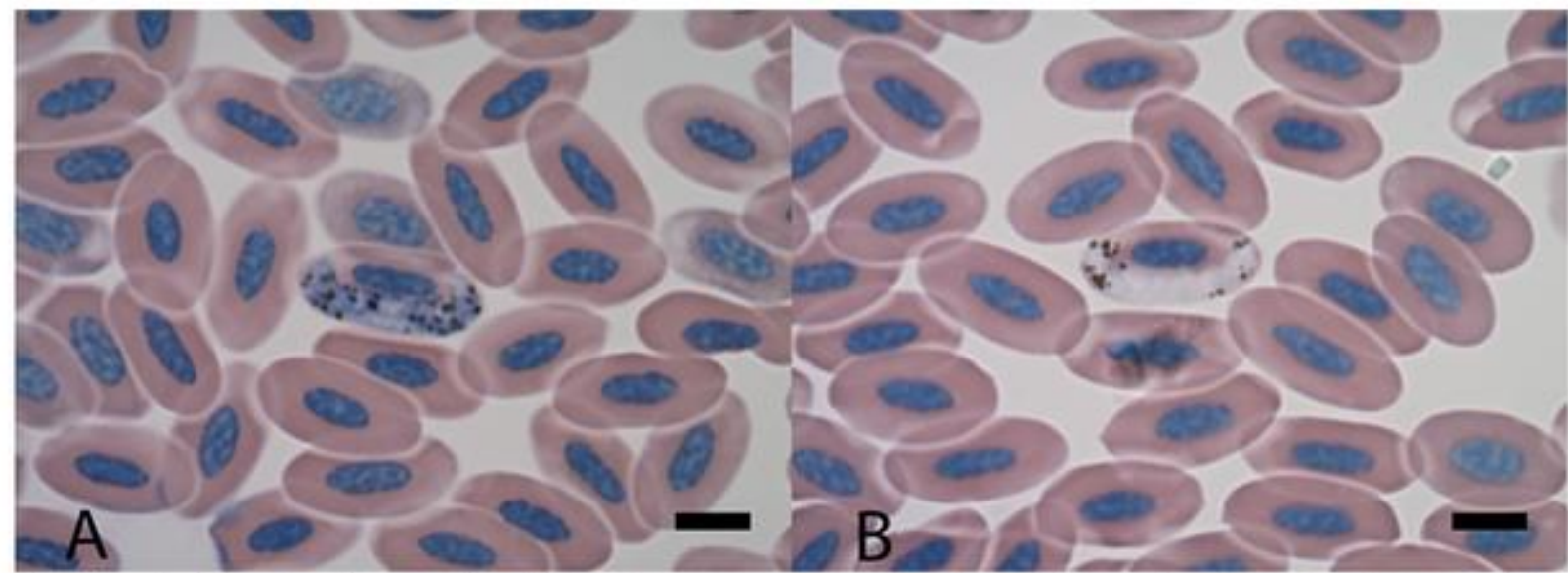

Figure 2. Photomicrograph of typical macrogametocytes (A) and microgametocytes (B) of Haemoproteus columbae identified in blood smears of Columbina talpacoti. Bars $-5 \mu \mathrm{m}$. 
Haemosporidian parasites were relatively uncommon (2.29\%) compared to studies conducted in Brazil using microscopy ${ }^{(19-23)}$. Habitat modification can increase the prevalence of these parasites ${ }^{(24)}$ and the low prevalence might be explained by the protection of the habitat and its avifauna. In all three positive cases, the low parasitemia and the high proportion of gametocytes suggest these were chronic and subclinical infections, for which blood smears are known to have inferior detection in comparison to PCR tests ${ }^{(25,26)}$. If chronic infections with low parasitemia are the rule in the studied population, it is likely that our study underestimated the true prevalence of these parasites. All positive samples came from $C$. talpacoti, whereas individuals from other species known to frequently host haemosporidians, such as the as Rupornis magnirostris ${ }^{(23)}$, Elaenia cristata $^{(20)}$, Formicivora grisea, Turdus leucomelas ${ }^{(21,23,26)}$ and Coereba flaveola ${ }^{(22)}$, were found to be negative in our study. The haemoparasite found here were morphologically compatible with Haemoproteus columbae, a species that has been reported in $C$. talpacoti $^{(27,28)}$, including in Brazil ${ }^{(27,29)}$. Although the frequency of this parasite may have been overall low, three out of the four $C$. talpacoti examined in this study were infected. This finding is consonant with the high prevalence observed earlier ${ }^{(29)}$ for this species in Southeast of Brazil; however, unlike those authors, we did not observe hippoboscid flies - the invertebrate hosts of Haemoproteus - under the feathers of any of the examined birds. Other blood-sucking dipteran insects (Diptera) can be implied as vectors of haemosporidian parasites in birds ${ }^{(15)}$.

Fecal samples were obtained from 48 individuals, and gastrointestinal parasites were detected in three of these samples (6.25\%): eggs of Spirurida (Nematoda, Spirurida) were found in a sample from Lanio cristatus; eggs of Strongyloides sp. (Nematoda, Strongyloididae) were found in a sample from Momotus momota and oocysts of Isospora sp. (Apicomplexa, Eimeriidae) were found in a sample from Neopelma pallescens. We suggested that the Spirurida eggs belonged to Habronematoidea superfamily based on Vicente et al. ${ }^{(30)}$ who registered the parasitism of Tetrameres minima in L. cristatus (previously Tachyphonus cristatus). To our knowledge, there are no previous studies examining fecal samples of wild birds for gastrointestinal parasites in Northeast of Brazil; however, a study of captive birds ${ }^{(31)}$ demonstrated the circulation of helminths and protozoans in the avifauna populations of the region. The three bird species found to be parasitized by gastrointestinal parasites are primarily insectivores but occasionally consume fruits and insects ${ }^{(32)}$. Omnivorous birds are more susceptible to gastrointestinal parasitism because of the variability of the diet, and arthropods can be intermediate hosts or vectors of parasites in insectivorous birds ${ }^{(33)}$. As reported previously ${ }^{(34)}$, none of the birds we found infested with gastrointestinal parasites presented external signs of disease.

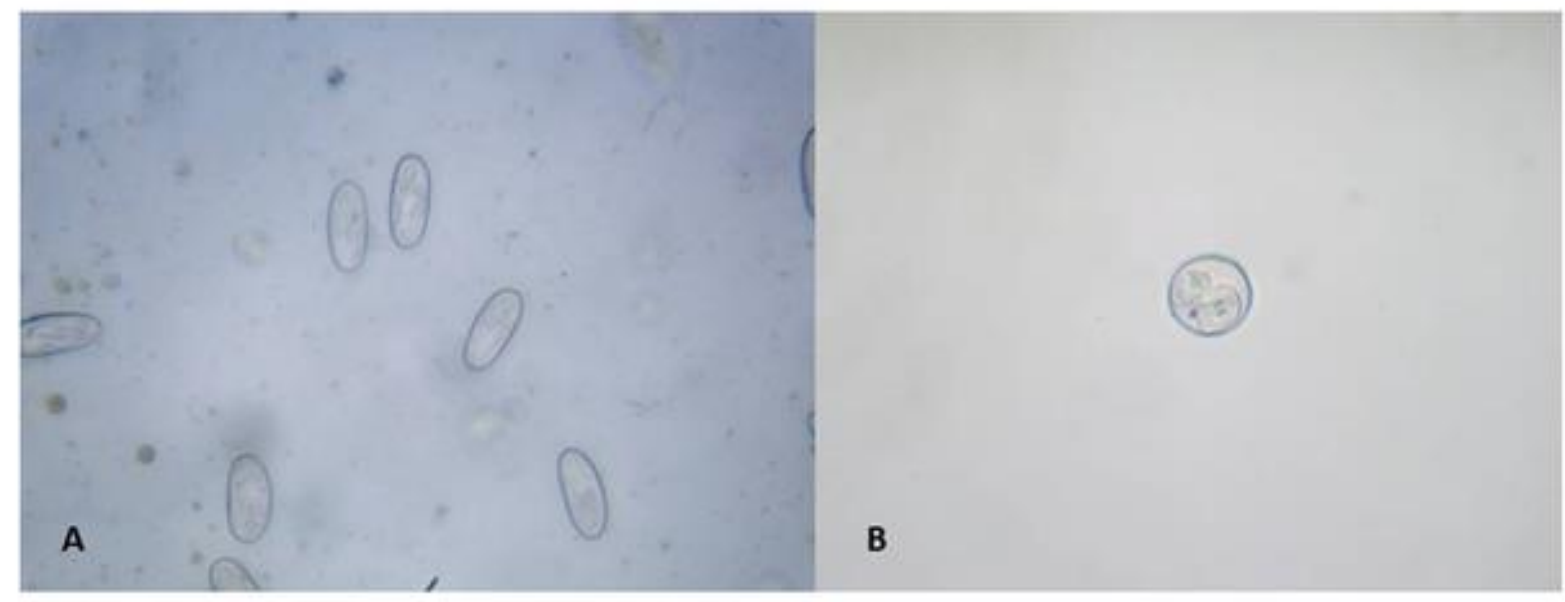

Figure 3. Photomicrograph of eggs of Spirurida (Nematoda, Spirurida) found in a sample from Lanio cristatus (A); oocysts of Isospora sp. (Apicomplexa, Eimeriidae) found in a sample from Neopelma pallescens (B). 


\section{Conclusion}

There is limited information on the parasites of wild birds in the remaining fragments of Atlantic forest in Northeast of Brazil, and the knowledge on parasites can help understanding these host-parasite interactions. We identified birds in Guaribas Biological Reserve parasitized by protozoans Haemoproteus columbae and Isospora sp., and the nematodes Spirurida and Strongyloides sp. Our future plans are to screen birds with molecular tools to better understand the biological and medical patterns of host-parasite in this area.

\section{Acknowledgments}

We are thankful to the Programa de Iniciação Científica CNPq/ICMBio and to the São Paulo Research Foundation (FAPESP 2009/53956-9) for funding and support. We are also thankful to Prof. José Luiz CatãoDias and Laboratório de Patologia Comparada de Animais Selvagens (LAPCOM-USP). Jean C. R. Silva receive a fellowship from the National Center for Scientific and Technological Development (CNPq). Jaqueline Bianque de Oliveira receive a fellowship from Programa de Educação Tutorial (PET) do Ministério de Educação (MEC).

\section{References}

1. Myers N, Mittermeier RA, Mittermeier CG, Fonseca GAB, Kent J. Biodiversity hotspots for conservation priorities. Nature. [Internet]. 2000: 403: 853-858. Available at: http://www.nature.com/nature/journal/v403/n6772/pdf/403853a0.pdf. English.

2. Daszak P, Cunningham AA, Hyatt AD. Emerging infectious diseases of wildlife - threats to biodiversity and human health. Science. [Internet]. 2000: 287: 443-449. Available at: http://people.ucsc.edu/ cwilmers/ENVS220/Daszak\%20et\%20al\%202000\%20Science.pdf. English.

3. Calegaro-Marques C, Amato SB. Helminths of introduced house sparrows (Passer domesticus) in Brazil: does population age affect parasite richness? Iheringia. [Internet]. 2010: 100:73-78. Available at: http://www.scielo.br/scielo.php?script=sci arttext\&pid=S0073-47212010000100010. English.

4. Delgado-V CA, French K. Parasite-bird interactions in urban areas: Current evidence and emerging questions. Landscape Urban Plan [Internet] 2012: 105:5-14. Available at: http://www.sciencedirect.com/science/article/pii/S0169204611003707. English.

5. Duffy DC. The ecology of tick parasitism on densely nesting Peruvian seabirds. Ecology. [Internet]. 1983: 64: 110-119. Available at: http://www.esajournals.org/doi/abs/10.2307/1937334. English.

6. Brown CR, Brown MB, Rannala B. Ectoparasites reduce long-term survival of their avian host. Proceedings of the Royal Society B: Biological Sciences. [Internet]. 1995: 262: 313-319. Available at: http://www.rannala.org/reprints/1995/Brown1995a.pdf. English.

7. Bencke GA, Mauricio GN, Develey PF, Goerck JM. Áreas importantes para a conservação das aves no Brasil. Parte I - Estados do domínio da Mata Atlântica. São Paulo, SAVE Brasil [Internet] 2006. 494 p. Available at: http://savebrasil.org.br/wp/wp-content/uploads/2013/11/Areas-Importantes-para-Conservacaodas-Aves Parte 1.pdf. Portuguese.

8. Almeida ACC, Teixeira DM. Aves da Reserva Biológica Guaribas, Mamanguape, Paraíba, Brasil. Revista Nordestina de Biologia. [Internet]. 2010: 19:3-14. Available at: http://periodicos.ufpb.br/ojs/index.php/revnebio/article/view/2601. Portuguese. 
9. Santos T, Oliveira JB, Vaughan C, Santiago H. Health evaluation of an ex situ population of raptors (Falconiformes and Strigiformes) in Mexico: diagnosis of internal parasites. Revista de Biologia Tropical. [Internet]. 2011: 59:1265-1274. Available at: http://www.ncbi.nlm.nih.gov/pubmed/22017131. English.

10. Foreyt WJ. Parasitologia Veterinária: manual de referência. 5th ed. São Paulo: Roca; 2005. 248 p. Portuguese.

11. Zajac AM, Conboy GA. Veterinary Clinical Parasitology. 7th ed. Ames: Blackwell Publishing Professional; 2006. 320 p. English.

12. Owen JC. Collecting, processing, and storing avian blood: a review. Journal of Field Ornithology. [Internet]. 2011: 82:339-354. Available at: http://www.fw.msu.edu/ owenj/Owen\%202011\%20Collecting\%20Processing\%20Blood.pdf. English.

13. Rosenfeld G. Corante pancrômico para hematologia e citologia clínica. Nova combinação dos componentes do May-Grunwald e do Giemsa num só corante de emprego rápido. Memórias do Instituto Butantan. 1947: 20:329-335. Portuguese.

14. Valkiūnas G, Iezhova TA, Krizanauskiene A, Palinauskas V, Sehgal RN, Bensch S. A Comparative Analysis of Microscopy and PCR-Based Detection Methods for Blood Parasites. The Journal of Parasitology. [Internet]. 2008: 94: 1395-1401. Available at: http://www.ncbi.nlm.nih.gov/pubmed/18576856. English.

15. Valkiūnas G. Avian malaria parasites and other Haemosporidia. London: CRC Press; 2005. 946 p. English.

16. Godfrey Jr RD, Fedynich AM, Pence DB. Quantification of hematozoa in blood smears. Journal of Wildlife Diseases. [Internet]. 1987: 23:558-565. Available at: http://jwildlifedis.org/doi/pdf/10.7589/0090-355823.4.558. English.

17. Gering E, Atkinson CT. A rapid method for counting nucleated erythrocytes on stained blood smears by digital image analysis. Journal of Parasitology. [Internet]. 2004: 90:879-881. Available at: http://www.ncbi.nlm.nih.gov/pubmed/15357090. English.

18. Piacentini VQ, Aleixo A, Agne CE, Maurício GN, Pacheco JF, Bravo GA, Brito GRR, Naka, LN, Olmos F, Posso S, Silveira LF, Betini GS, Carrano E, Franz I, Lees AC, Lima LM, Pioli D, Schunck F, Amaral FR, Bencke GA, Cohn-Haft M, Figueiredo LFA, Straube FC, Cesari E. Annotated checklist of the birds of Brazil by the Brazilian Ornithological Records Committee/Lista comentada das aves do Brasil pelo Comitê Brasileiro de Registros Ornitológicos. Revista Brasileira de Ornitologia [Internet] 2015: 23: 91-298. Available at: http://www4.museu-goeldi.br/revistabrornito/revista/index.php/BJO/article/view/1263. English.

19. Fecchio A, Marini MÂ, Braga ÉM. Baixa prevalência de hemoparasitos em aves silvestres no Cerrado do Brasil Central. Neotropical Biology and Conservation. [Internet]. 2007: 2: 127-135. Available at: https://www.researchgate.net/publication/238753620_Baixa_prevalncia_de_hemoparasitos_em_aves_silvest res no Cerrado do Brasil Central Low prevalence of blood parasites in Cerrado birds Central Brazil. Portuguese.

20. Fecchio A, Lima MR, Silveira P, Braga ÉM, Marini MÂ. High prevalence of blood parasites in social birds from a neotropical savanna in Brazil. Emu. [Internet]. 2011: 111:132-135. Available at: http://www.publish.csiro.au/paper/MU10063.htm. English.

21. Sebaio F, Braga EM, Branquinho F, Fecchio A, Marini MÂ. Blood parasites in passerine birds from the Brazilian Atlantic Forest. Revista Brasileira de Parasitologia Veterinária [Internet]. 2012: 21:7-15. Available at: http://www.ncbi.nlm.nih.gov/pubmed/22534938. English.

22. Leite Y FC, Torres RTP, Braga ÉM. Prevalência de Hemosporideos em três localidades do Estado do Tocantins, Brasil. Ornithologia. [Internet]. 2013: 6: 1-13. Available at: http://cemave.net/ornithologia/index.php/ornithologia/article/view/103. Portuguese. 
23. Brum WM, Pereira MAVC, Vita GF, Ferreira I, Mello ER, Aurnheimer RCM, Sanavria A, Padua ED. Parasitismo em aves silvestres residentes e migratórias da Ilha da Marambaia, Estado do Rio de Janeiro. Pesquisa Veterinária Brasileira. [Internet]. 2016: 36:1101-1108. Available at: http://www.scielo.br/scielo.php?pid=S0100-736X2016001101101\&script=sci_abstract\&tlng=pt..

Portuguese.

24. Ferreira Junior FC, Rodrigues RA, Ellis VA, Leite LO, Borges MAS, Braga EM. Habitat modification and seasonality influence avian haemosporidian parasite distributions in southeastern Brazil. PLoS ONE [Internet]. 2017: 12: e0178791. Available at: http://journals.plos.org/plosone/article?id=10.1371/journal.pone.0178791. English.

25. Garamszegi LZ. The sensitivity of microscopy and PCR-based detection methods affecting estimates of prevalence of blood parasites in birds. The Journal of Parasitology. [Internet]. 2010: 96:1197-1203. Available at: http://www.ncbi.nlm.nih.gov/pubmed/21158636. English.

26. Belo NO, Pinheiro RT, Reis ES, Ricklefs RE, Braga EM. Prevalence and Lineage Diversity of Avian Haemosporidians from Three Distinct Cerrado Habitats in Brazil. PLoS ONE, 6:e17654. [Internet] 2011. Available at: http://www.plosone.org/article/info\%3Adoi\%2F10.1371\%2Fjournal.pone.0017654. English.

27. Bennet GF, Lopes OS. Blood parasites of some birds from São Paulo State, Brazil. Memórias do Instituto Oswaldo Cruz. [Internet]. 1980: 75:117-34. Available at: http://www.scielo.br/scielo.php?pid=S007402761980000100012\&script=sci_arttext. English.

28. Peirce MA. A checklist of the valid avian species of Babesia (Apicomplexa: Piroplasmorida), Haemoproteus, Leucocytozoon (Apicomplexa: Haemosporida), and Hepatozoon (Apicomplexa: Haemogregarinidae). Journal of Natural History. [Internet]. 2005: 39:3621-3632. Avaliable at: http://www.tandfonline.com/doi/abs/10.1080/00222930500340534\#.U3whTvldWVM. English.

29. Adriano E, Cordeiro NS. Prevalence and Intensity of Haemoproteus columbae in Three Species of Wild Doves from Brazil. Memórias do Instituto Oswaldo Cruz. [Internet]. 2001. 96: 175-178. Available at: http://www.ncbi.nlm.nih.gov/pubmed/11285493. English.

30. Vicente JJ, Rodrigues HO, Gomes DC, Pinto RM. Nematóides do Brasil. Parte IV. Nematóides de aves. Revista Brasileira de Zoologia [Internet]. 1995: 12 (Supl. 1): 1-273. Available at: http://www.scielo.br/scielo.php?script=sci_arttext\&pid=S0101-81751995000500001. Portuguese.

31. Freitas MFL, Oliveira JB, Cavalcanti MD, Leite AD, Magalhães VS, Oliveira RA, Sobrinho AE. Parasitos gastrointestinales de aves silvestres en cativeiro en el estado de Pernambuco, Brasil. Parasitologia Latinoamericana. [Internet]. 2002: 57:50-54. Available at: http://www.scielo.br/scielo.php?pid=S1984$29612013000200314 \&$ script=sci_arttext\&tlng=pt. Spanish.

32. Sigrist T. Guia de campo Avis Brasilis: avifauna brasileira. Avis Brasilis, São Paulo, 2009. 1080 p. Portuguese.

33. Costa IA, Coelho CD, Bueno C, Ferreira I, Freire RB. Ocorrência de parasitos gastrintestinais em aves silvestres no município de Seropédica, Rio de Janeiro, Brasil. Ciência Animal Brasileira. [Internet]. 2010. 11: 914-922. Available at: http://www.revistas.ufg.br/index.php/vet/article/view/7164. Portuguese.

34. Marietto-Gonçalves GA, Fernandes TM, Silva RJ, Lopes RS, Andreatti Filho RL. Intestinal protozoan parasites with zoonotic potential in birds. Parasitology Research. [Internet]. 2008: 103:1237-1240. Available at: http://link.springer.com/article/10.1007\%2Fs00436-008-1125-y\#page-1. English. 